\title{
15: 64466679-64570936
}

National Cancer Institute

\section{Source}

National Cancer Institute. 15: 64466679-64570936. NCI Thesaurus. Code C45023.

Physical location of MAP2K1_Gene 